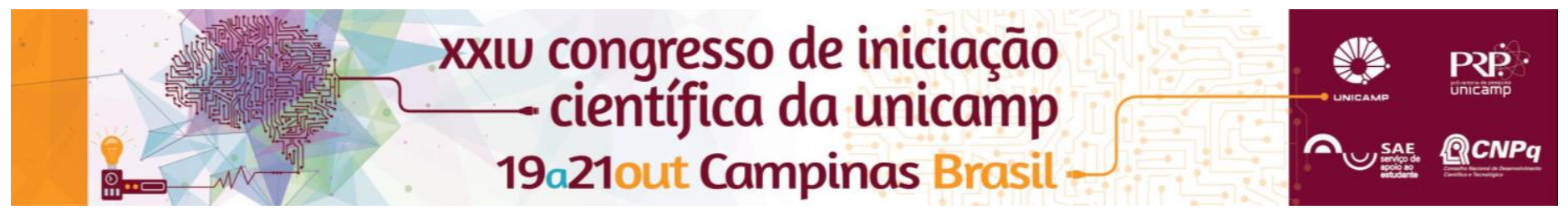

\title{
A arte carranqueira do São Francisco: estudo da inserção das carrancas nas barcas através de desenhos e modelos.
}

\section{Victor Doratiotto Churchill*}

\section{Resumo}

Este projeto de pesquisa estuda os métodos envolvidos no processo construtivo das carrancas em sua relação com as barcas são-franciscanas, com enfoque na inserção da figura de proa na embarcação. Neste estudo foram elaborados desenhos técnicos de diferentes geometrias de carrancas e composições de proa das barcas, analisando os diferentes tipos de barcas, o desenho formado pelo conjunto com a escultura, as relações construtivas deste conjunto e a técnica de encaixe da figura na proa. Com estes desenhos foram confeccionados, através da técnica da talha, modelos em escala que representam as técnicas construtivas abordadas na consolidação da carranca como figura de proa.

\section{Palavras-chave}

Escultura, talha, carranca.

\section{Introdução}

Este trabalho dá continuidade ao projeto de iniciação científica "A arte carranqueira do São Francisco: estudo e construção de figuras de proa", de mesma autoria. A fim de estudar e compreender todo o processo de execução da escultura, este projeto acompanha a junção da carranca na barca; a consolidação da figura de proa. Através da pesquisa bibliográfica e imagética e com a confecção de desenhos bidimensionais foram analisadas as técnicas de encaixe da figura na proa, configurando então uma nova extensão da embarcação. Com este estudo e como produto final desta pesquisa foram confeccionados modelos e maquetes tridimensionais de madeira em escala utilizando a técnica da talha abordada no primeiro projeto de pesquisa, passando então por todas as etapas do processo construtivo de uma carranca.

\section{Resultados e Discussão}

Todo o processo de pesquisa mostra a interação entre a carranca e a barca sendo transportada do ateliê do escultor carranqueiro para o conjunto formado na proa. Todas as carrancas analisadas nesta pesquisa, tanto pelo material bibliográfico e imagético quanto na visita à exposição "A Viagem das Carrancas" na Pinacoteca do Estado de São Paulo (durante o período compreendido pela pesquisa), possuíam características semelhantes em relação ao encaixe da figura na proa, o que possibilitou a confecção dos modelos físicos com um planejamento bastante objetivo. Com os desenhos confeccionados no primeiro semestre da pesquisa, estes modelos são apresentados como o produto final deste projeto de iniciação científica.

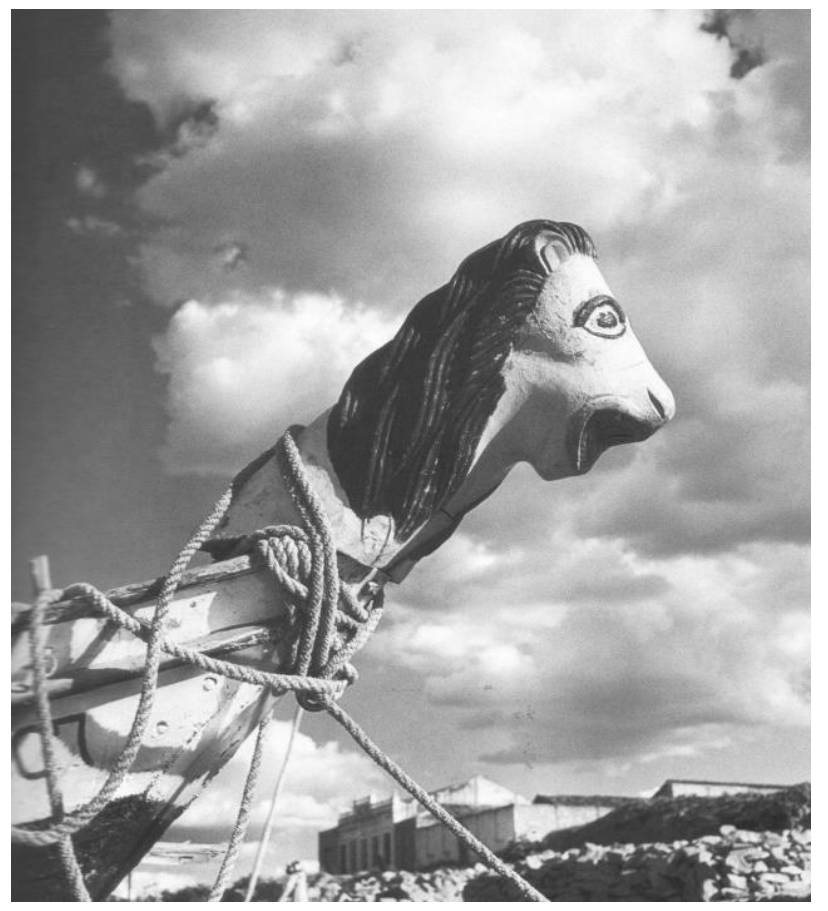

Figura 1. Carranca da barca Anhancá (MAMMì, pág. 91, por Marcel Gautherot)

\section{Conclusões}

Com o processo de montagem da figura na barca sendo identificado em diversas fotografias das carrancas originais e comprovado pelas observações feitas na visita às peças originais é certo dizer havia uma interação entre a técnica construtiva adotada na fabricação naval e a talha como técnica artística, unindo através do uso da madeira dois universos criativos distintos. 